Global Conferences Series:

Social Sciences, Education and Humanities (GCSSSEH), Volume 2, 2019

The $2^{\text {nd }}$ International Conference on Sustainable Development \& Multi-Ethnic Society

DOI: https://doi.org/10.32698/GCS.0178

\title{
Museum Based Learning in History Education to Enhance Patriotism among Students
}

\author{
Lelawathi Napiah ${ }^{1}$, Mahzan Awang ${ }^{2}$, Abdul Razaq Ahmad ${ }^{3}$, Shakila Che Dahalan ${ }^{4}$ \\ ${ }^{1234}$ Faculty of Education UKM, MALAYSIA \\ E-mail: lela.mumtazah90@gmail.com
}

\begin{abstract}
People still assume that a museum is simply a place where things are collected and displayed for the visitors to have a look at. However, simultaneously, they did not realize that there is no learning process in occurring. Basically, museum based learning can be more related in history education to improves patriotism. Museum based learning is a process of teaching outside the classroom in the study of history subject. The use of museum as outdoor learning tool can enhance the value of patriotism among students. Most researchers only focus on teaching and learning in the classroom. The purpose of this paper is to give knowledge to students about the importance of museum-based learning, to create good moral values and to expose the students to experiences the reality. In this regard, this paper will discuss about types of exploration activities within the museum that are suitable for implementation, challenges and suggestions for improvement of students so that it can enhance student's interest in patriotism. Through this writing, it is hoped that it will serve as a source of reference for future researchers making the museum as a medium of outdoor learning.
\end{abstract}

Keywords: museum-based learning, history education, outdoor learning, patriotism, moral value

\section{Introduction}

Starting from 2013, the Malaysian Ministry of Education (MOE) has made the History subject in schools as a passcompulsory subject in the Malaysian Certificate of Education (Sijil Pelajaran Malaysia). This change in curriculum is aimed at producing students that can build interest towards history as a dynamic discipline of knowledge and excel in historical studies as well as shaping a competitive society on a national and international level (Centre of Curriculum development, 2015). It is hoped that the decision made can help students to further understand the situation of this country by creating a spirit of unity among people of different races, inculcate love for the nation as well as upholding its sovereignty (Wilbinah, 2013 cited from. Anuar, Siti Haishah, \& Nur Atiqah, 2009). The application of high order thinking skills, communicative skills, critical thinking and a spirit of teamwork in supporting $21^{\text {st }}$ Century Learning Skills (PAK-21) among pupils must be implemented by all teachers during the teaching and learning process (PdP).

According to the Malaysian Education Blueprint, from the year 2013 to 2015, the government intends to instill six key attributes in every pupil. These attributes include being Knowledgeable, Ethical and Spiritual as well as possessing good Thinking Skills, Leadership Skills, Bilingual Proficiency and a sense of National Identity for them to be able to compete on a global scale (Malaysian Ministry of Education, 2013). This proves that the nation 
seeks to produce a young generation that possesses adequate skills and knowledge to face the demands of the global market as well as having a patriotic spirit which is a naturally-born love for the country. Patriotic values include being Proud as a Malaysian, Loyalty to the Nation, the Spirit of Togetherness, Disciplined, Hardworking and Productive (Nazri \& Jamsari, 2004). Therefore, patriotic values must be inculcated at an early age. This is because children that love the nation will grow to appreciate its heritage, diversity, history and will subsequently work hard to elevate Malaysia in all aspects (Lee, 2016).

In accordance to that, the government's proposition for learning to be held outside of the classroom (PLBD or Outdoor Learning) is an accurate move to ensure a learning environment that is more meaningful. One of the three models of outdoor learning which can be chosen for implementation, according to the needs and capabilities of the school, is outdoor learning, held far from the school compound, which requires approval from the District Education Office (PPD) and the State Education Department (JPN). Thus, through collaboration with the Ministry of Education, the museum bears a significant social responsibility to educate the society, specifically pupils, as a potentially attractive desirable location for outdoor teaching and learning of history. The participation of pupils in activities organized by the museum will indirectly instill patriotic values as well as the lifelong nation-building education through deep understanding, knowledge and appreciation regarding Malaysia (Ab. Samad, Zuraidah, Yusmilayati, 2010).

\section{The Importance of Museums}

The use of genuine history artefacts (teach and touch concept) would make the history learning more fun and interesting (S. Azman et al., 2017). According to Marcus et al. (2012), the use of genuine artefacts deepens the pupils' understanding towards the content of a particular historical material as well as developing historical thought and literacy skills not available in the classroom such as seeing, touching and experiencing the past. In Western Europe, education in museums frequently occurs through the senses of sight, touch, smell and taste (Tišliar, 2017). This Open Store Concept is practiced in several museums overseas. In fact, the visitors of those museums are given permission to see and use the collections of artefacts available in storage (Ab Samad et al., 2012).

Whereas for history topics with difficult-to-obtain artifacts, pictures and videos can be shown to pupils. This way, pupils will be able to effectively remember chronological events in history which were taught in the classroom without the need to memorize particular facts. For example, the diorama of the Pangkor Treaty at the National Museum in Gallery C (Colonial Era) helps pupils to better understand the treaty via the vivid representation of the treaty itself on board the H.M.S Pluto rather than having to read about the treaty over and over again (S. Azman et al., 2017). A study done by S. Azman et al. (2017) proves that learning history in a museum setting, is an outdoor learning instrument which helps the pupils' understanding towards the concepts of history taught in the classroom.

Sharipah \& Arba'Iyah (2016) stated that history learning in the classroom is rather abstract in nature, whereas, in museums or historical places, it becomes more realistic. An example of this is the Keris display in the Museum Department of Malaysia. One of the interactive activities available is the usage of the 'Sense Card' that moves artefacts (Ab Samad et al., 2010). It would be easier for the pupils to understand history if they possess the experience interacting with the relics and artefacts available in the museum. They learn to transform their opinions, attitudes, and appreciation around the evidence that they have seen (Lord, 2007). This, in turn, positively affects pupils to become productive people who appreciate and preserve national treasures like these for future generations.

Excursions to the museum can expose the pupils to new experiences via the simulation programs held. Also, through the said excursion, activities which require the pupils to move around and be active can be done in the lesson conducted in the museum (Nur Syazwani, Kamarulzaman \& Nur Azuki, 2019). A study done by Lezah Kiamsin \& Rosy Talin (2018) found that 'Gallery Walk' is a popular method of learning among pupils. This method is very effective in increasing student cooperation as it requires them to complete the group assignment. Besides that, it also fosters good relations among pupils, teamwork and the exchange of ideas in completing the work.

In accordance with the importance of museum in the implementation of Outdoor Learning, the Inspirasi Pelajar Inovasi Muzium or the Pupil Inspiration Museum 1nnovation (1P1M) program was launched by the Museum Department of Malaysia (JMM) and the Ministry of Education (MOE) in March 2015. This 'workshop themed' programme aims to encourage pupils from level 2 primary schools (standard 3 to 6) to form five pupils in secondary schools to visit museums. At least one museum for one level of education. Different groups of pupils can materialize a harmonious learning environment, simultaneously exchanging views and ideas with pupils from other schools. This is similar to Hanisah's (2011) view, saying that a different learning environment can 
increase the pupils understanding towards history as well as inculcating values and patriotic behaviour.

\section{Challenges of Museum-Based Learning}

Wan Zahid (1993) opines that a nation that in order to build a strong and noble nation, one must not merely look into technological and material developments but also upon developments revolving around culture, knowledge, virtuous behavior, self-confidence, responsibility and self-sacrifice. These values should also be the structure on which a strong nation stands. A lack in appreciation of patriotic values will result in pupils who are easily influenced by foreign elements, fall victim to numerous social ills and become divided (Nazri \& Jamsari, 2004). Museum-based learning is vital in increasing the patriotic spirit among pupils. However, there are several challenges in making museum-based learning as one of the methods of outdoor learning.

Every museum has its own objective of establishment and in different categories. For example, the artefact collection in a Federal Museum such as the National Museum is different from a museum under the supervision/ jurisdiction of specified departments like Military Museums, State Museums, Private Museums, University Museums and Privately-Owned Museums (Zuraidah \& Ab Samad, 2015). The focus content of history curriculum in secondary schools includes the comprehension and appreciation of Malaysian history. The history of our nation is learnt and studied chronologically from the Ice Age up until the establishment of Malaysia according to given themes (MOE, 2015). This situation will give off a different view of history from what is taught in the classroom because the artefacts in the museum are not arranged in the same way or sequence as the content of the history textbook. Consequently, this will give off a different understanding of history towards the pupils and thus, cause a negative perception towards the museum excursion itself.

The current situation of education that is heavily exam-oriented forces the teacher and the pupils to rely on textbooks (Ahmat Adam, 2013). Due to that, teachers have no other choice but to finish the syllabus as soon as possible. Besides that, the society prefers to look at success in certain exams as the benchmark for determining a pupil's success in the future (Noraizan, 2008). In fact, the time allotted in schools for this factual-based learning of history is very limited, much less for an excursion to the museum. Thus, it is not surprising that some teachers do not have the time to organise an excursion, specifically to the museum, due to their workload.

Next, the pupils' negative perception towards the subject itself is also a challenge. They assume that achieving a good grade in history will not guarantee them a well-paying job and that learning in school is merely a ticket for them to sit for exams and eventually, obtain the education certificate (Sharipah \& Arba'Iyah, 2016). A study conducted by Nur Syazwani et al. (2019) found that interest among form four pupils in excursions to the museum is influenced by their own behavior towards the History subject itself.

Furthermore, before organizing an excursion, teachers need to make early and detailed preparations. There are several forms that need to be filled in by the teachers. A few examples include the paperwork of the program itself, letter of application for the trip to the District Education Office (PPD) as well as to the museum intended for the excursion. Also, it is not recommended for activities outside of school to be held during school hours as it would disrupt the learning hours of other subjects. This procedure places a great deal of pressure on the teachers, who are already burdened with other academic and non-academic responsibilities (Norashid \& Hamzah, 2014). Hence, it is not surprising that teachers are more comfortable by only utilizing the indoor approach towards the teaching of history

\section{Strategies in Making the Museum as an Informal Medium of Learning}

A study by Rashidah, Badrul, Zuraimi \& David (2015) showed that a high percentage of teachers agree that museums need to be exposed to educational programmes and activities that are cognitively stimulating and effective as well as pupil psychomotor education. For teachers, aside from guided excursions, prefer exploring objects in museums and live demonstrations. A guideline should also be given to teachers, so that excursions conducted by said teachers can positively impact the pupils. Also, the guideline can provide an opportunity for the teachers and the museum to fulfill their respective needs and thus, be able to materialise interesting potential.

An effective history teacher must have a wellsupported background in history as well as enough professional training, especially in the field of history (Sharipah \& Arba'Iyah, 2016). They should be ready with the academic discipline and are well versed in the subject-matter at hand, in order to ensure a better pedagogical grasp. In this case, teachers need to see the museum itself and plan suitable activities with the museum administrators before having the field trip. A free and easy excursion with no activities might leave a bad perception among pupils towards the museum field trip as they would see it an utter waste of time and a once in a lifetime visit is enough (S. Azman et al., 2017). 
As a study conducted by Çil, Maccario \& Yanmaz (2016) suggests, extensive preparation is required before the museum excursion is held. These preparations include preexcursion preparations, teaching strategies during the excursion itself and activities after the excursion as postlesson reinforcement activities. The participants of the excursion gave positive feedback in regards to this method of approaching museum-based learning. Interestingly, this study involved participants who were future teachers from the faculty of education in an institution for tertiary education in Turkey. They were exposed to the museum environment in their third year before being sent for their practicum semester in schools.

Since every museum has its own unique objective behind its establishment, teachers need to select the museums that fit in with the textbook topics already covered in school. As an example, the National Museum in Kuala Lumpur has a gallery that displays all the information and evidence pertaining to the cultural history (Cultural Material) of early civilizations in Malaysia. This period of time is known as the Stone Age, based on the discovery of artefacts made from stone and primitive drawings on walls of caves like the ones found in Kota Tampan (Perak), Gua Niah (Sarawak), Ulu Tembeling (Perak) and Tingkayu (Sabah) (JMM, n.d). In accordance to that, the learning activities these museums are very suitable for form one pupils as they fit the new Secondary School Curriculum Standard (KSSM) syllabus. This excursion will be more meaningful and beneficial for the said pupils as they can be related to the topics learnt in class.

A study done by Nur Syazwani et al. (2019) shows that there is a relationship between the behavior of pupils towards the history subject and their interest in participating museum excursions. An interest towards history must be instilled among pupils, in order to ensure their interest in learning history and visiting the museum. Thus, teachers play an important role to be creative and innovative in their lessons and are fully responsible for the interest of pupils towards the history subject. Anuar \& Nelson (2015) suggests that a history teacher should be able to diversify the strategies used and their teaching methodology in an orderly and systematic manner. Additionally, teachers that involve pupils in the process of teaching and learning in class will bring about a more effective impact towards the purpose of history education itself. As a study done by Lezah \& Rosy (2018) states that pupil are more inclined towards studentcentered activities like presentations, debates, gallery walks, and Q\&A sessions. When the teacher succeeds in attracting the pupils' interest towards learning history, the pupils' perceptions toward history will be positive and consequently, will be more interested to participate in museum excursions.

\section{Conclusion}

This paperwork proves that patriotic values can be further enhanced and inculcated through museum-based learning as pupils are exposed to a historical environment and a new surrounding beyond the walls of a classroom. The "Night at the Museum" program, launched by the Museum Department of Malaysia since 2016, is capable of attracting the youth as they are the determiners of today's national identity and the successor of its culture. Learning via museum excursions has had a positive effect on the learning of history. Findings from Siti Suzainah \& Abdul Razaq's (2015) research indicate that museum excursions are highly effective. However, the limitations of the research include the museum's policies and the commitment of pupils in completing their assignments given during the excursion. Thus, a new study pertaining to programs, organized by certain museums, and its relationship with academic institutions in implementing said programs as well as its effectiveness to inculcate patriotic values among pupils should be done. This is so that today's generation can comprehend the meaning of understanding, tolerance, unity, harmony as well as being accepting of other cultures in order to shape their identity, aside from having good moral values and thus, ready to become future leaders of the nation.

\section{References}

[1] Ab. Samad Kechot, Zuraidah Hassan \& Yusmilayati Yunos. (2010). Proses Pendidikan Muzium: Satu Kajian Awal. Jurnal Melayu (5): 285-293.

[2] Ab. Samad Kechot, Shahidi A.Hamid, Rahim Aman, Zuraidah Hassan \& Daeng Haliza Daeng Jamal. (2012). Pendidikan Warisan di Muzium: Kajian berkaitan penggunaan laras bahasanya (The Language of heritage education in Malaysian Museum). Geografia: Malaysians Journal of Society and Space, 8 (8).pp.3546.

[3] Ahmat Adam. (2013). Ucaputama yang disampaikan dalam Seminar Kebangsaan Pendidikan dan Geografi anjuran Sekolah Pendidikan dan Pembangunan Sosial Universiti Malaysia Sabah, Kota Kinabalu Sabah pada 29 0gos 2013. Retrieve from https://www.ums.edu.my/fpp/images/stories/Document/ SPSG2013/ucap\%20utama\%201\%20pendidikan\%20sej arah\%20di\%20malaysia\%20dewasa\%20ini.pdf.

[4] Anuar Ahmad \& Nelson Jinggan. (2015). Pengaruh Kompetensi Kemahiran Guru Dalam Pengajaran Terhadap Pencapaian Akademik Pelajar Dalam Mata Pelajaran Sejarah. JuKu: Jurnal Kurikulum \& Pengajaran Asia Pasifik, 3(2), 1-11.

[5] Anuar Ahmad, Siti Haishah Abdul Rahman \& Nur Atiqah T.Abdullah. (2009). Tahap keupayaan pengajaran Guru Sejarah dan hubungannya dengan 
pencapaian murid di sekolah berprestasi rendah. Jurnal Pendidikan Malaysia 34(1)(2009): 53 - 66.

[6] Çil, E., Maccario, N., \& Yanmaz, D. (2016). Design, implementation and evaluation of innovative science teaching strategies for non-formal learning in a natural history museum.Research in Science \& Technological Education, 34(3), 325-341.

[7] Garis Panduan Pembelajaran Luar Bilik Darjah (PLBD): Pendidikan Sivik dan Kewarganegaraan. (2006). Pusat Perkembangan Kurikulum. Kementerian Pendidikan Malaysia.

[8] Kementerian Pendidikan Malaysia. (2013). Pelan Pembangunan Pendidikan Malaysia 2013-2025. Putrajaya: Kementerian Pendidikan Malaysia.

[9] Lezah@ Lejah dan Rosy Binti Talin.(2018). Teaching Method of History Preferred by Students and Its Justifications. Malaysian Journal of Social Sciences and Humanities (MJSSH), 3(2), 137-145.

[10] Lee, L.T. (2016). Patriotisme dalam Diri Rakyat Malaysia.Utusan Online 22 September 2016.

[11]Lord, B. (2007). The Manual of Museum Learning. Altamira Press. A division of Rowman \& Littlefield Publishers Inc: Lanham.New York.Toronto.Plymouth,UK.

[12] Marcus, A.S., Stoddard,J.D, \& Woodward,W.W (2012). Teaching History with museum. New York, NY: Routledge.

[13] M.Kaviza, Fauziah Abdul Rahim \& Nurliyana Bukhari. (2018). Tahap Kesediaan Guru-Guru Sejarah Dalam Melaksanakan Kedah Pengajaran dan Pembelajaran Berasaskan Sumber Sejarah : Satu Tinjauan di Negeri Perlis. JuKu: Jurnal Kurikulum \& Pengajaran Asia Pasifik, 6(2), 23-31.

[14] Nazri Muslim \&Jamsari Alias. (2004). Patriotisme: Konsep dan pelaksanaannya di Malaysia. In: Seminar Antarabangsa Nilai dalam Komuniti Pasca Modenisme (SIVIC 2004), 4-6 September 2004, Hotel City Bayview Langkawi.

[15] Noraizan Hamzah@ Daud. (2008). Persespsi Pelajar dan Guru Terhadap Penggunaan Buku Teks Sejarah. Kertas Projek Sarjana. Universiti Kebangsaan Malaysia.

[16] Norashid Othman \& Hamzah Md. Omar.(2014). Beban tugas dan motivasi pengajaran Guru di Sekolah Menengah Daerah Ranau. Jurnal Pemikir Pendidikan, 5.

[17]Nor Hanisah.(2011). Pengenalan Kepada Dunia Permuziuman. Jabatan Muzium Malaysia. Kuala Lumpur.

[18] Nur Syazwani Abdul Talib, Kamarulzaman Abdul Ghani, and Nur Azuki Yusuff.(2019). Kaedah Pembelajaran Sejarah Berasaskan Lawatan Ke Muzium. International Online Journal of Language, Communication, and Humanities, 2(1), 45-57.
[19]Pusat Perkembangan Kurikulum. (2015). Dokumen Standard Kurikulum dan Pentaksiran Mata Pelajaran Sejarah Tingkatan Satu. Putrajaya: Kementerian Pendidikan Malaysia.

[20] Rashidah Salim, Badrul Isa, Zuraimi Zakaria, \& David Forrest. (2015). From Classroom to Museum: A Preliminary Study of Teachers' Preferences of Formal Learning Experiences in Museum Setting.In. Zuraimi Zakaria, Badrul Isa,\& Sumardianshah Silah (Eds.), Volume 2-2 $1^{\text {st }}$ CENTURY SKILLS:Language and Arts EducationThrough the Lens of Culture and Heritage. Institut Terjemahan \& Buku Malaysia Berhad (ITBM) and Universiti Teknologi Mara.

[21] Siti Suzainah Muhamad \& Abdul Razaq Ahmad.(2015). Pembelajaran Sejarah Menerusi Lawatan ke Muzium.National. Research Seminar 2015.9 Mei 2015.UPSI.

[22] S. Azman Ligun, Mohd Mahzan Awang, Abdul Razaq Ahmad, Mohd Isa Hamzah \& Nor Wahida Hasan.(2017). Muzium Sebagai Instrumen Pembelajaran Sejarah Luar Bilik Darjah. JuKu: Jurnal Kurikulum \& Pengajaran Asia Pasifik, 5(1), 19-30.

[23] Sharipah Aini dan Arba'iyah Mohd Noor.(2016). Pelaksanaan Pengajaran dan Pembelajaran Sejarah di Sekolah -Sekolah di Malaysia, 1957-1989, 25(2,3). doi: 10.22452/sejarah.vol25no.2.3

[24] Tišliar, P. (2017). The Development of Informal Learning and Museum Pedagogy in Museums. Slovak Republic European Journal of Contemporary Education ISSN 2304-9650 E-ISSN 2305-6746 2017, 6(3): 586-592.

[25] Wan Zahid Wan Nordin. (1993). Wawasan Pendidikan: Agenda Pengisian. Kuala Lumpur: Nurin Enterprise.

[26]Zuraidah Hassan \& Ab. Samad Kechot, (2015). Pengelolaan dan Pengurusan Muzium Negara: Sejarah dan Struktur. Jurnal Arkeologi Malaysia (28): 86-101. 